\title{
Red Algae as Source of Nutrients with Antioxidant and Antimicrobial Potential
}

\author{
María. Carpena 1,2, Cristina Caleja ${ }^{2}$, Paula García-Oliveira 1,2, Carla Pereira ${ }^{2}$, Marina Sokovic ${ }^{3}$, \\ Isabel C. F. R. Ferreira ${ }^{2}$, Jesús Simal-Gandara ${ }^{1}$, Lillian Barros ${ }^{2, *}$ and Miguel A. Prieto ${ }^{1, *}$
}

Citation: Carpena, M.; Caleja, C.; García-Oliveira, P.; Pereira, C.; Sokovic, M.; Ferreira, I.C.F.R.; SimalGandara, J.; Barros, L.; Prieto, M.A. Red Algae as Source of Nutrients with Antioxidant and Antimicrobial Potential. Proceedings 2021, 70, 5. https://doi.org/10.3390/ foods_2020-07646

Published: 9 November 2020

Publisher's Note: MDPI stays neutral with regard to jurisdictional claims in published maps and institutional affiliations.

Copyright: $@ 2020$ by the authors. Licensee MDPI, Basel, Switzerland. This article is an open access article distributed under the terms and conditions of the Creative Commons Attribution (CC BY) license (http://creativecommons.org/licenses/by/4.0/).
1 Nutrition and Bromatology Group, Faculty of Food Science and Technology, University of Vigo, Ourense Campus, E32004 Ourense, Spain; maria.carpena.rodriguez@uvigo.es (M.C.); paula.garcia.oliveira@uvigo.es (P.G.-O.); jsimal@uvigo.es (J.S.-G.)

2 Centro de Investigação de Montanha (CIMO), Instituto Politécnico de Bragança, Campus de Santa Apolónia, 5300-253 Bragança, Portugal; ccaleja@ipb.pt (C.C.); carlap@ipb.pt (C.P.); iferreira@ipb.pt (I.C.F.R.F.)

3 Institute for Biological Research "Siniša Stanković" - National Institute of Republic of Serbia, University of Belgrade, Belgrade 11060, Serbia; mris@ibiss.bg.ac.rs (M.S.)

* Correspondence: lillian@ipb.pt (L.B.); mprieto@uvigo.es (M.A.P.)

+ Presented at the 1st International Electronic Conference on Food Science and Functional Foods, 10-25 November 2020; Available online: https://foods_2020.sciforum.net/.

\begin{abstract}
Seaweeds have been consumed since ancient times in different cultures, especially in Asian regions. Currently, several scientific studies have highlighted the nutritional value of algae as well as their biological properties. The present work was directed towards the determination of the nutritional composition (ash, protein, fat, carbohydrate content and energy value), the organic acids content, and also the antioxidant and antimicrobial activity of three typical red algae from Galicia: Chondrus crispus, Mastocarpus stellatus and Gigartina pistillata. The nutritional profile was determined by the methods described by AOAC, while organic acids were determined by UPFLCPDA. The antioxidant activity was assessed using two in vitro assays: TBARS and OxHLIA. At last, antimicrobial activity was tested against two Gram (-), three Gram (+) and three fungus species. The results showed a similar nutritional composition among the three algae, with a low-fat content and a high content of proteins, carbohydrates and energy. Finally, in vitro assays showed significant antioxidant capacity of the three algae and antimicrobial potential against all the tested microorganisms. Thus, the study shows the potential of red algae to be part of the human diet, due to their nutritional content and bioactive properties, acting as antioxidant and antimicrobial agents.
\end{abstract}

Keywords: red algae; nutritional value; chemical characterization; antioxidant; antimicrobial

Supplementary Materials: The following are available online at www.mdpi.com/25043900/70/1/5/s1.

Institutional Review Board Statement: Not applicable.

Informed Consent Statement: Not applicable.

Data Availability Statement: Data sharing is not applicable to this article.

Acknowledgments: The authors are grateful to the Foundation for Science and Technology (FCT, Portugal) and FEDER under Programme PT2020 for financial support to CIMO (UID/AGR/00690/2019); national funding by FCT, P.I., through the institutional scientific employment program-contract for L. Barros and C. Pereira's contract though the celebration of program-contract foreseen in No. 4, 5 and 6 of article $23^{\circ}$ of Decree-Law No. 57/2016, of 29th August, amended by Law No. 57/2017, of 19th July; research contract of C. Caleja (Project AllNatt, POCI- 01-0145-FEDER-030463); and to FEDER-Interreg España-Portugal programme for financial support through the project TRANSCOLAB 0612_TRANS_CO_LAB_2_P. The research leading to these results was funded by FEDER under the program Interreg V Spain-Portugal by POPTEC, IBERPHENOL Project (ref. 0377Iberphenol-6-E) and by NANOEATERS Project (ref. 0181-NANOEATERS-01-E), by MICINN 
supporting the Ramón \& Cajal grant for M. A. Prieto (RYC-2017-22891); by Xunta de Galicia for supporting the pre-doctoral grant of P. García-Oliveira (ED481A-2019/295); by EcoChestnut Project (Erasmus+ KA202) supporting the work of M. Carpena; by Ibero-American Program on Science and Technology (CYTED-AQUA-CIBUS, P317RT0003); by UP4HEALTH Project (H2020-BBI-JTI-2019); by Axudas Conecta Peme (Xunta de Galicia) supporting the IN852A 2018/58 NeuroFood Project and by AlgaMar (www.algamar.com). 